\title{
Intensive care admission in patients with hellp syndrome in a tertiary referral hospital
}

\author{
E Gedik $^{1 *}$, N Yücel ${ }^{2}$, T Sahin $^{3}$, E Koca ${ }^{4}$, YZ Çolak², T Togal ${ }^{2}$ \\ From ESICM LIVES 2015 \\ Berlin, Germany. 3-7 October 2015
}

\section{Introduction}

Every year, 500.000 mothers die from pregnancy-related complications, and $99 \%$ of these deaths occur in low- and middle-income countries [1]. These maternal deaths occur from complications associated with pre-eclampsia or eclampsia; hemolysis elevated liver enzymes, and low platelet (HELLP) syndrome, or other hypertensive disorder of pregnancy [2].

\section{Objectives}

To identify risk factors affecting maternal outcome among women with Hemolysis, Elevated Liver Enzymes, and Low Platelets (HELLP) syndrome who required transfer for critical care.

\section{Methods}

All 77 women with HELLP syndrome who sought care for delivery and postpartum assessment at the emergency department, and who were treated in our intensive care unit between January 2007 and July 2012 were identified, retrospectively. Findings were analyzed according to surviving and non-surviving patients.

\section{Results}

Maternal mortality rate was $14 \%$ and perinatal death occurred in 24 of 81 fetuses and newborn (30\%). The most common cause of maternal complications was disseminated intravascular coagulation in 22 patients (29\%), acute renal failure in 19 patients (25\%), and postpartum hemorrhage in 16 patients (21\%). Compared with surviving women, non-surviving women had higher mean values for international normalized ratio $(p<0.0001)$, levels of serum aspartate aminotransferase $(p<0.0001)$, serum alanine aminotransferase $(p<0.0001)$, lactate dehydrogenase

${ }^{1}$ Baskent University, Ankara, Turkey

Full list of author information is available at the end of the article $(p<0.0001)$, and bilirubin $(p=0.040)$ and lower platelet count $(p=0.005)$.

\section{Conclusions}

The patients with HELLP syndrome should be treated in intensive care unit, especially after cesarean delivery. Disseminated intravascular coagulation is major risk factor affecting maternal outcome.

\section{Authors' details}

${ }^{1}$ Baskent University, Ankara, Turkey. ${ }^{2}$ Inonu University, Malatya, Turkey. ${ }^{3}$ Ersin Arslan State Hospital, Gaziantep, Turkey. 'Malatya State Hospital, Malatya, Turkey.

Published: 1 October 2015

\section{References}

1. World Health Organization: The World Health Report 2005: make every mother and child count. Geneva, World Health Organization; 2005.

2. Duley L: The global impact of pre-eclampsia and eclampsia. Semin Perinatol 2009, 33:130-7.

doi:10.1186/2197-425X-3-S1-A909

Cite this article as: Gedik et al:: Intensive care admission in patients with hellp syndrome in a tertiary referral hospital. Intensive Care Medicine Experimental 2015 3(Suppl 1):A909.

Submit your manuscript to a SpringerOpen ${ }^{\odot}$ journal and benefit from:

- Convenient online submission

- Rigorous peer review

- Immediate publication on acceptance

- Open access: articles freely available online

- High visibility within the field

- Retaining the copyright to your article

Submit your next manuscript at $>$ springeropen.com (c) 2015 Gedik et al.; This is an Open Access article distributed under the terms of the Creative Commons Attribution License (http:// creativecommons.org/licenses/by/4.0), which permits unrestricted use, distribution, and reproduction in any medium, provided the original work is properly cited. 